\title{
Differential Expression of the Insulin Gene Transcriptional Repressor CCAAT/Enhancer-binding Protein $\beta$ and Transactivator Islet Duodenum Homeobox-1 in Rat Pancreatic $\beta$ Cells During the Development of Diabetes Mellitus
}

\author{
Jochen Seufert, ${ }^{\star}$ Gordon C. Weir, ${ }^{\ddagger}$ and Joel F. Habener* \\ *Laboratory of Molecular Endocrinology, Massachusetts General Hospital, Howard Hughes Medical Institute, Harvard Medical School, \\ Boston, Massachusetts 02114; and Islet Transplantation and Cell Biology Section, Joslin Diabetes Center, Boston, Massachusetts 02115
}

\begin{abstract}
Impairment of insulin secretion due to prolonged hyperglycemia is believed to contribute to the manifestation of diabetes mellitus, often referred to as glucose toxicity of pancreatic $\beta$ cells. In addition, impaired $\beta$ cell function has been associated with elevated islet triglyceride content (lipotoxicity). Impaired functions of the transactivating factors islet duodenum homeobox-1 (IDX-1) and RIPE3b-binding proteins have been implicated in the pathological downregulation of insulin gene transcription by high glucose levels in pancreatic $\beta$ cell lines in vitro, and, similarly, the exposure of pancreatic islets to fatty acids decreases IDX-1 expression. Previously, we identified the basic leucine zipper transcription factor CCAAT/enhancer-binding protein $\beta(\mathrm{C} /$ EBP $\beta$ ) as an inhibitor of insulin gene transcription in pancreatic $\beta$ cells and showed that the expression of $C / E B P \beta$ is upregulated in insulinoma-derived $\beta$ cell lines by sustained high glucose concentrations. Here we describe the regulation of the expression of IDX-1, C/EBP $\beta$, and insulin at the mRNA and protein levels in pancreatic islets in animal models of diabetes mellitus. Concomitant with a downregulation of IDX-1 and insulin expression, C/EBP $\beta$ is upregulated in association with the manifestation of hyperglycemia during the development of diabetes in the Zucker diabetic fatty ( $f a / f a)$ rat and in the $90 \%$ pancreatectomy rat model of diabetes. This regulation is demonstrated to influence both the amount of cellular protein and the level of steady state messenger RNA. Our findings indicate that the differential dysregulation of both IDX- 1 and C/EBP $\beta$, in response to sustained hyperglycemia or hyperlipidemia, may be involved in the impairment of insulin gene expression during the manifestation of diabetes mellitus. (J. Clin. Invest. 1998. 101:2528-2539.) Key words: glucose toxicity $\bullet$ lipotoxicity $\bullet$ insulin gene $\bullet$ transcription factors $\bullet$ diabetes mellitus
\end{abstract}

Address correspondence to Joel F. Habener, Laboratory of Molecular Endocrinology, Massachusetts General Hospital, Wellman Bldg. 320, 50 Blossom Street, Boston, MA 02114. Phone: 617-726-5190; FAX: 617-726-6954; E-mail: habenerj@a1.mgh.harvard.edu

Received for publication 5 December 1997 and accepted in revised form 9 March 1998.

J. Clin. Invest.

(C) The American Society for Clinical Investigation, Inc. 0021-9738/98/06/2528/12 \$2.00

Volume 101, Number 11, June 1998, 2528-2539

http://www.jci.org

\section{Introduction}

The disease diabetes mellitus predisposes to premature morbidity and mortality. Diabetes is a result of a failure of the $\beta$ cells of the endocrine pancreas to produce the amounts of insulin required to dispose of glucose, resulting in elevated blood glucose levels (hyperglycemia). Sustained hyperglycemia leads to a further impairment of insulin production by $\beta$ cells, socalled glucose toxicity $(1,2)$. The experimental exposure of insulinoma cell lines and human islets in vitro to elevated glucose concentrations impairs glucose-responsive insulin secretion and insulin biosynthesis $(3,4)$. Moreover, the lowering of hyperglycemia in diabetic animal models leads to recovery of adequate insulin secretion by pancreatic $\beta$ cells (5).

In addition to the impairment of glucose-responsive insulin secretion, high glucose concentrations induce a corresponding paradoxical reduction of insulin gene transcription (3). This circumstance has been attributed, at least in part, to a downregulation of the transcription factors islet duodenum homeobox-1 (IDX-1) ${ }^{1}$ and the RIPE3b1-binding protein(s). Diminished activity of these transactivating proteins on the insulin gene promoter, associated with reduced cellular insulin content, mRNA, and secretion, has been observed in studies of insulinoma cell lines in vitro upon chronic exposure to high glucose levels for several weeks (6-8). These effects were only partially reversible upon subsequent incubation in lower glucose concentrations (9), implying the involvement of other, potentially inhibitory, regulatory factors in the glucotoxic impairment of insulin gene transcription in pancreatic $\beta$ cells. We have identified the basic leucine zipper transcription factor CCAAT/enhancer-binding protein $\beta(\mathrm{C} / \mathrm{EBP} \beta)$ as such a negative regulatory factor on insulin gene transcription in pancreatic $\beta$ cells (10). In addition, a reversible reduction of the specific binding of IDX-1 and the RIPE3b1-binding protein to their respective DNA elements was observed as early as $72 \mathrm{~h}$ after exposure to high glucose levels in the $\beta$ cell line INS- 1 (11). A downregulation of IDX-1 in response to elevated glucose levels was further demonstrated in vivo in a rat model of diabetes secondary to $90 \%$ pancreatectomy (12).

In addition to the deleterious effects of high glucose levels on $\beta$ cell function, elevated serum triglyceride and free fatty acid concentrations, as well as triglyceride accumulation in pancreatic islets during the development of diabetes mellitus, have been associated with impaired $\beta$ cell secretory responses $(13,14)$. More recently, alterations in $\beta$ cell gene regulation have been reported in this context (15).

The production of insulin by pancreatic $\beta$ cells is highly

1. Abbreviations used in this paper: $\mathrm{C} / \mathrm{EBP} \beta, \mathrm{CCAAT} /$ enhancer- $^{-}$ binding protein $\beta$; FFA, free fatty acids; IDX-1, islet duodenum homeobox-1; ROI, region of interest; RT, reverse transcription; ZDF, Zucker diabetic fatty. 
regulated at the level of insulin gene transcription (16). The rat genome contains two nonallelic insulin genes (I and II), regulated by distinct promoters and contributing equivalently to insulin gene expression (17). The sequences that account for $90 \%$ of the promoter activity of the rat insulin-I gene lie within $\sim 400 \mathrm{bp}$ of the proximal $5^{\prime}$ untranslated region.

The major transcription factors that regulate basal and glucose-responsive insulin gene transcription are the homeodomain-containing protein IDX-1 (synonym: pancreas duodenum homeobox-1, insulin promoter factor-1, somatostatin transactivating factor-1), binding to the A-elements (far-linked AT-rich, P1) of the insulin gene promoters (18), and transcription factors of the basic helix-loop-helix family that bind to the E-elements (Nir, Far; references 19-21).

The CCAAT/enhancer-binding proteins are a family of basic leucine zipper transcription factors involved in the regulation of genes of the acute phase response (22), tissue development, and differentiation, such as adipogenesis (23), hormonal regulation (24), and hematopoiesis (25). The members of the family identified to this point are $\mathrm{C} / \mathrm{EBP} \alpha, \mathrm{C} / \mathrm{EBP} \beta$ (NF-IL6, LAP, IL6-DBP, AGP/EBP, CRP2, NF-M), C/EBPy (Ig/EBP), C/EBP $\delta$ (NF-IL6- $\beta$, CRP3), C/EBP $\epsilon$, and CHOP-10. Upon phosphorylation and nuclear translocation the C/EBPs bind to specific DNA-recognition sequences as dimers (26). These factors can act as transcriptional activators as well as repressors (27).

In earlier studies we identified the expression of $\mathrm{C} / \mathrm{EBP} \beta$ in pancreatic $\beta$ cells and in rat islets and demonstrated that the expression of this transcription factor is regulated by glucose in the pancreatic $\beta$ cell lines HIT-T15 and Ins-1 (10). We found a partial irreversibility of the upregulation of $\mathrm{C} / \mathrm{EBP} \beta$ expression after long-term exposure, and complete reversibility after short-term exposure of insulinoma cell lines to high glucose levels (10), similar to the findings of the downregulation of IDX-1 expression in these same glucose desensitization models $(3,11)$. In addition we demonstrated that $\mathrm{C} / \mathrm{EBP} \beta$ acts as a transcriptional regulator of the expression of the insulin gene. In particular, opposing actions of $\mathrm{C} / \mathrm{EBP} \beta$ on insulin gene transcription were observed in $\beta$ cells compared with non- $\beta$ cells. In non- $\beta$ cells $C / E B P \beta$ stimulated the rat-insulin I promoter through interactions with a novel enhancer element, the $\mathrm{CEB}$ box. In contrast, $\mathrm{C} / \mathrm{EBP} \beta$ acts as a transcriptional repressor of the insulin gene in pancreatic $\beta$ cells via mechanisms involving physical and functional interaction with the basic helixloop-helix transcription factor E47. Thereby, C/EBP $\beta$ inhibits the DNA-binding and transactivation potentials of E47, which leads to reduced insulin promoter activity in pancreatic $\beta$ cells.

Although information about the regulation of transcription factor expression derived from studies of insulinoma cells in vitro may be useful, it is also limited. The cells are transformed, generally poorly responsive to changes in glucose levels, and, at least in HIT cells, require many weeks of passage to manifest glucotoxicity. Continued passage raises concerns about the clonal selection of cells that may obscure the data obtained. Studies done in vitro beg the question of what happens to the expression of transcription factors during the development of diabetes in intact animal models in vivo. Therefore we examined whether $\mathrm{C} / \mathrm{EBP} \beta$ and IDX-1 expression may also be regulated in the endocrine pancreas in vivo in the context of supraphysiological glucose levels. Here we report on the characterization of $\mathrm{C} / \mathrm{EBP} \beta$, IDX-1, and insulin expression in two different hyperglycemic animal models, the Zucker diabetic fatty $(\mathrm{fa} / \mathrm{fa})$ rat (28), and the rat model of $90 \%$ pancreatectomy (29), and provide evidence for an involvement of both $\mathrm{C} / \mathrm{EBP} \beta$ and IDX-1 in the pathophysiological pathways of the development of diabetes mellitus as mediators of glucotoxic or lipotoxic impairment of $\beta$ cell function in vivo.

\section{Methods}

Laboratory animals. Male Zucker diabetic fatty $(f a / f a)$ rats at the ages of 7, 9, and $12 \mathrm{wk}$, lean littermates $(f a /+)$, and Wistar rats were obtained from Genetic Models, Inc. (Indianapolis, IN). Animals were maintained on an ad libitum diet with commercial chow (Laboratory rodent diet No. 5001; PMI Nutrition International, St. Louis, MO) with a fat content of $4.5 \%$ and a protein content of $23 \%$. Sprague Dawley rats, 4-5 wk of age, were obtained from Taconic Farms, Inc. (Germantown, NY).

Serum insulin and glucose measurements. Serum insulin concentrations were determined by a specific radioimmunoassay (30). Glucose concentrations were measured in serum on a Glucose Analyzer (2300 STAT; Yellow Springs Instrument Co., Yellow Springs, OH). Values for the Zucker diabetic fatty $(f a / f a)$ rat model represent fed values, determined in the late morning, whereas those for the rat model of $90 \%$ pancreatectomy were determined after an overnight fast in the early morning.

Semiquantitative fluorescence immunocytochemistry. Animals were anesthetized, weighed, and serum was obtained by heart puncture. Excised pancreata were embedded in cryosection medium (OCTcompound, tissue tek; Miles Laboratories, Inc., Elkhart, IN) and immediately frozen on dry ice. 5- $\mu \mathrm{m}$ sections were double stained in a single series with rabbit antiserum against C/EBP $\beta$ (Santa Cruz Biotechnology, Inc., Santa Cruz, CA) or IDX-1 (18), and a guinea pig antiserum to insulin (31). Fluorescent secondary antisera coupled to Cy-3 (indocarbocyanine) or DTAF (dichlorotriazinylamino fluorescein) were from Jackson ImmunoResearch Laboratories (West Grove, PA). To minimize variability between different sections, the staining procedures for all sections and antisera were performed simultaneously and in parallel with the same batches of solutions and antisera. In addition the same incubation times for fixation, permeabilization, blocking, and exposure to antisera were employed for all processed sections. After staining, the semiquantitative assessment of fluorescence intensity was performed for all sections in one single series to avoid alterations in signal intensities over time. For fluorescence intensity measurements the microscopic images, obtained with a Nikon epifluorescent microscope, were analyzed by image quantitation software (IP-Lab Spectrum; Signal Analytics Co., Vienna, VA) after digitizing with constant grabbing parameters, i.e., fluorescence sampling time, brightness, contrast and color correction, for all sections by an Optronics TEC-470 CCD camera (Optronics Engineering, Goleta, CA) interfaced with a PowerMac 7100. Intensity calibration was conducted to account for the dynamic range of digitization because of the characteristics of the sensor of the CCD camera and the lighting characteristics, as well as to approximate linearity in fluorescence measurements. This was achieved by linearizing the raw pixel intensities of each grabbed image to floating-point data values according to a function derived from the quantitation of a set of images obtained from one islet over a range of different fluorescent sampling times. In each adjusted image, the islet used for quantitation was defined as region of interest (ROI) by marking the islet border with the freehand tool. The average fluorescent intensity within the ROI was then determined by analysis of pixel intensity and is independent of the area of the measured ROI. The average fluorescent intensity of ten islets per tissue section and three tissue sections for each animal (three animals per group) was determined. The fluorescence values, obtained from sections stained only with secondary antiserum, were considered to reflect the nonspecific fluorescent background, and were subtracted from the ROI values above. Values are expressed as means $\pm \mathrm{SD}$. 
Islet isolation. Rats were anesthetized and islets were isolated by a modified collagenase digestion method as described previously (32). Briefly, after cannulation of the common bile duct, the pancreas was perfused with RPMI 1640 medium (GIBCO BRL, Life Technologies, Gaithersburg, MD) containing $2 \mathrm{mg} / \mathrm{ml}$ collagenase P (Boehringer Mannheim Biochemicals, Indianapolis, IN) and $0.5 \mathrm{mg} / \mathrm{ml}$ DNase I (Sigma Chemical Co., St. Louis, MO), followed by dissection of the organ and digestion at $37^{\circ} \mathrm{C}$ in a shaking waterbath. After washing with HBSS (GIBCO BRL, Life Technologies), the islets were concentrated by centrifugation through a Histopaque (Sigma Chemical Co.) gradient, followed by manual isolation.

Western immunoblotting. Whole cell extracts from isolated islets were prepared by lysis in RIPA-buffer $(150 \mathrm{mM} \mathrm{NaCl}, 20 \mathrm{mM}$ Tris $\mathrm{Cl}, \mathrm{pH}$ 7.5, 1 mM EDTA, 1\% NP-40, 1\% Deoxycholate, 0.1\% SDS, $5 \mathrm{mM} \mathrm{NaF}$ ). $20 \mu \mathrm{g}$ of extract per sample were fractionated on a $12 \%$ SDS-polyacrylamide gel, transferred to a PVDF-membrane (Immobilon-P; Millipore Corp., Bedford, MA) and probed with a rabbit $\mathrm{C} / \mathrm{EBP} \beta$ antiserum (Santa Cruz Biotechnology Inc.) or a rabbit IDX-1 antiserum (18). Specific bands were visualized by enhanced chemiluminescence (ECL; Amersham International, Little Chalfont, Buckinghamshire, UK).

Rat model of $90 \%$ pancreatectomy and chronic hyperglycemia. 4-5wk-old Sprague Dawley rats underwent $90 \%$ pancreatectomy or were sham operated as described previously (12). Removal of the pancreas was performed by abrasion with cotton applicators. Sham surgery consisted of an identical procedure, except that the whole pancreas was left in situ and only slightly manipulated. Islets from the pancreatic remnants and the sham-operated animals were isolated at 1, 2, and $4 \mathrm{wk}$ after operation. Body weight and blood glucose levels were obtained before surgery and at the time of islet harvest.

Competitive semiquantitative reverse transcription PCR. Total RNA from islets was extracted by the single-step guanidinium-isothiocyanate method (33) with a commercial reagent $\left(\right.$ TRIZOL $^{\circledR}$; GIBCO BRL, Life Technologies). Islet preparations of five animals (Zucker rats), or two to three animals of both pancreatectomized and shamoperated animals of each time point were pooled. RNA extracted from islets of Zucker rats was quantitated by $\mathrm{OD}_{260 / 280}$ measurement and gel electrophoresis. Equal amounts per pool of isolated RNA were subjected to reverse transcription. RNA isolated from pancreatic remnants of pancreatectomized rats was reverse transcribed without prior quantitation in duplicate or triplicate samples by oligodT priming with Moloney murine leukemia virus reverse transcriptase (Superscript; GIBCO BRL, Life Technologies). After reverse transcription (RT), double stranded cDNA/RNA-heteroduplexes were quantitated by intercalating fluorescence dye analysis (Pico Green; Molecular Probes, Inc., Eugene, OR) on a Fluor Imager 575 (Molecular Dynamics, Sunnyvale, CA). Suitability of the Pico Green dye for the quantification of cDNA/RNA heteroduplexes was tested by comparing the fluorescence emission spectrum of cDNA/ RNA samples after reverse transcription at an excitation wavelength of $480 \mathrm{~nm}$ on an LS-3B fluorescence spectrometer (Perkin Elmer Ltd., Beaconsfield, Buckinghamshire, UK), to the spectra of doublestranded DNA, yielding comparable results (data not shown). Identical amounts of such quantified cDNA were subjected to PCR analysis. For quantitation purposes, the following competitor templates were constructed, so that both wild type and competitor sequences could be amplified by the same primer oligonucleotides, but yielded products of different length. The plasmid C/EBP $\beta$-pcDNA I (34) was cut with FspI, thereby removing 27 bp of C/EBP $\beta$ sequence between the oligonucleotide priming sites, and blunt-end ligated to $284 \mathrm{bp}$ of foreign DNA, thus adding 257 bp to the $\mathrm{C} / \mathrm{EBP} \beta$ sequence. For IDX-1, a 349-bp PCR-product, obtained with the same primers, used for quantitative PCR, and amplified from the plasmid IDX-1-pBJ5 (18), was subcloned into pCR 2.1 by TA-cloning, cut with MluI and BlpI, filled in with Klenow-DNA-Polymerase, and religated, yielding a template with a 121-bp excision from the IDX-1 sequence. For insulin, the plasmid pRat Ins-I (a gift from Dr. S.J. Chan, Howard Hughes Medical Institute, University of Chicago, Chicago, IL; reference 35), containing $399 \mathrm{bp}$ of the rat insulin I gene coding sequence, was cut with StyI, filled in with Klenow-DNA-Polymerase and ligated to the same foreign DNA, that was used for the C/EBP $\beta$ standard, adding 292 bp to the sequence. 10-20 ng of competitor DNA were used in PCR reactions such that competition was directed to the amplification primers (36). In RT-PCR reactions of RNA from islets of pancreatectomized rats, endogenous $\beta$ actin was co-amplified in each reaction as a control to adjust for differences in cDNA input. PCR amplification was performed for $\mathrm{C} / \mathrm{EBP} \beta$ (sense primer: 5'-CGCCGCCTCCCGCCGCACTC-3', antisense primer: 5'-CAGCCGCTCGTTCTCCGCCGTCAG-3'), IDX-1 (sense primer: 5'-TGCTAATCCCCCTGCGTGCCTGTA-3', antisense primer: $5^{\prime}$-CTCCTCCGGTTCTGCTGCGTATGC-3'), and insulin (sense primer: $5^{\prime}$-CCTGCCCAGGCTT TTGTCA-3', antisense primer: 5'-GGTGCAGCACTGATCCACAATG-3') including intron border-spanning oligonucleotides for rat $\beta$ actin where applicable (sense primer: $5^{\prime}$ GATGACCCAGATCATGTTTG-3', antisense primer: 5'-GAGCAATGATCTTGATCTTC-3'), using Taq-Polymerase (TaKaRa; Takara Shuzo Co., Otsu, Japan) on a Gene Amp 9600 Thermal Cycler (Perkin-Elmer Corp., Norwalk, CT) under the following conditions: $\mathrm{C} / \mathrm{EBP} \beta$ : $60 \mathrm{~s} 95^{\circ} \mathrm{C}(1 \mathrm{cycle}), 45 \mathrm{~s} 95^{\circ} \mathrm{C}, 30 \mathrm{~s} 68^{\circ} \mathrm{C}, 30 \mathrm{~s} 72^{\circ} \mathrm{C}(20$ cycles); IDX-1: $30 \mathrm{~s} 94^{\circ} \mathrm{C}, 45 \mathrm{~s} 55^{\circ} \mathrm{C}, 30 \mathrm{~s} 72^{\circ} \mathrm{C}$ (22 cycles); and insulin: $30 \mathrm{~s} 94^{\circ} \mathrm{C}, 45 \mathrm{~s} 56^{\circ} \mathrm{C}, 45 \mathrm{~s} 72^{\circ} \mathrm{C}(20$ cycles $)$. Cycle numbers were determined to cover the exponential range of the amplification kinetics (data not shown), and similar amplification efficiency of the wild-type and standard templates was observed for each reaction by using wildtype and competitor sequence plasmids in serial dilutions (see inserts in Figs. 3 and 4). For each PCR sample, a negative control reaction without template was included, and to control for residual DNA contamination in the RNA preparations, an RT reaction without reverse transcriptase was amplified by PCR for each islet RNA sample (RTminus, not shown). Only RT-PCR reactions with negative results in the corresponding RT-minus samples were used for quantification. PCR products were subjected to agarose gel electrophoresis. After staining with ethidium bromide, the band intensities were quantitated on a Fluor Imager 575 using Image Quant Software (Molecular Dynamics) by rectangle mode/local background/volume integration and values normalized to the intensity of the competitor-bands and, where applicable, to the $\beta$ actin bands. Data are expressed as means of two to three different independent RT-PCR reactions \pm SEM.

\section{Results}

Protein expression of $C / E B P \beta$ and IDX-1 during the development of diabetes in the Zucker diabetic fatty (fa/fa) rat. To examine the expression of $\mathrm{C} / \mathrm{EBP} \beta$ and IDX-1 in pancreatic islets in vivo and to correlate the expression level to glucose homeostasis, we chose an animal model of genetically determined obesity and type 2 diabetes. The Zucker diabetic fatty ( $f a / f a$ ) rat develops a well-defined, age-dependent, phenotype consisting of the onset of obesity at the age of 5-7 wk accompanied by a metabolic state of early diabetes mellitus with hyperinsulinemia, insulin resistance, and moderate hyperglycemia (37). The full syndrome of diabetes develops at the age of 10-12 wk. The features of the pathogenetic manifestations of diabetes in this animal model are in many ways reminiscent of the pathogenesis of type 2 diabetes in humans. The $f a / f a$ genotype consists of a point mutation in the gene for the leptin receptor $(O b-R)$, leading to an alteration and impairment of the signaling capabilities of this receptor (38-41). The molecular mechanisms, however, that are involved in the development of the obese and diabetic phenotype are not understood. The Wistar strain of rats and the heterozygous $(f a /+)$ rats do not develop obesity or overt diabetes and serve as control animals. 
Table I. Characteristics of Wistar Rats, Heterozygous (fa/+), and Homozygous (fa/fa) Zucker Diabetic Fatty Rats at 7 and 12 Wk of Age

\begin{tabular}{lccccc}
\hline & Wistar & $f a /+$ & $f a l f a$ & $f a /+$ & $f a / f a$ \\
\multicolumn{1}{c}{ Group } & $7 \mathrm{wk}$ & $7 \mathrm{wk}$ & $7 \mathrm{wk}$ & 3 & $12 \mathrm{wk}$ \\
\hline$n$ & 3 & 3 & 3 & $351.7 \pm 18.9$ & $281.7 \pm 14.4$ \\
Body weight $(\mathrm{g})$ & $208.3 \pm 2.9$ & $278.3 \pm 22.5$ & $244.3 \pm 29.7$ & $130.3 \pm 14.6$ & $336.7 \pm 25.6$ \\
Plasma glucose $(\mathrm{mg} / \mathrm{dl})$ & $136.3 \pm 4.6$ & $109 \pm 9.5$ & $41.73 \pm 6.4$ & $9.6 \pm 2.2$ & $438 \pm 16.5$ \\
Plasma insulin $(\mu \mathrm{U} / \mathrm{ml})$ & $10.6 \pm 0.7$ & $10.4 \pm 2.2$ & & \\
\hline
\end{tabular}

Glucose and insulin represent fed values. Parameters represent the average \pm SEM of the number of animals per group.

Table I shows the body weights and parameters of glucose homeostasis in the animals of the different groups that were examined. Compared with Wistar rats and heterozygous littermates the homozygous $(f a / f a)$ animals exhibit substantially elevated body weights at 7 and 12 wk of age. Furthermore, the homozygous $(f a / f a)$ animals have markedly elevated serum insulin levels together with a successive rise of blood glucose from 7 to 12 wk as compared with heterozygous littermates and Wistar control rats. Thus the measured parameters validate the expected metabolic state of the animal model used.

To correlate the expression levels of the transcription factors $\mathrm{C} / \mathrm{EBP} \beta$ and IDX-1 to the status of insulin biosynthesis in pancreatic $\beta$ cells during the development of diabetes, we examined the expression of IDX-1, C/EBP $\beta$, and insulin by semiquantitative fluorescence immunocytochemistry in islets of $\mathrm{fa} /$ $f a$ rats at 7 and $12 \mathrm{wk}$ of age, and compared the results to control rats consisting of age-matched heterozygous $(f a /+)$ lean littermates and Wistar rats. We included the analysis of expression levels of the homeobox transcription factor IDX-1 to determine whether the activity of this factor is also altered during the development of diabetes in vivo as it has been shown in in vitro studies. On pancreatic tissue sections stained with hematoxylin and eosin, the islet morphology showed the expected hyperplasia in the Zucker rats as reported previously (reference 37, and data not shown). Fig. 1, $A-E$ shows representative sections of pancreatic islets, double stained for either $\mathrm{C} / \mathrm{EBP} \beta$ or IDX-1 and insulin. The results of the semiquantitative analysis of the average fluorescent intensity of pancreatic islets within each group of animals are summarized in Fig. $1 F$. When the average fluorescent intensity of the islets, stained for $\mathrm{C} / \mathrm{EBP} \beta$, IDX-1, and insulin in the different groups of animals (Fig. $1 F$ ) were compared, a marked induction of $\mathrm{C} / \mathrm{EBP} \beta$ expression in the hyperglycemic $f a / f a$ animals at $7 \mathrm{wk}$ (Fig. $1 C$ ) and an even more pronounced elevation at 12 wk of age (Fig. $1 E$ ) was detected. This correlated with the higher degree of hyperglycemia at week 12 compared with week 7 . In contrast normoglycemic Wistar rats at $7 \mathrm{wk}$ of age (Fig. $1 A$ ) and $\mathrm{fa} /+$ littermates at $7 \mathrm{wk}($ Fig. $1 \mathrm{~B})$ and $12 \mathrm{wk}($ Fig. $1 \mathrm{D})$ maintained constant low levels of $\mathrm{C} / \mathrm{EBP} \beta$ expression. Levels of the homeobox transcription factor IDX-1 were diminished in the homozygous animals in the prediabetic ( $7 \mathrm{wk}$, Fig. $1 C$ ) as well as the diabetic state ( $12 \mathrm{wk}$, Fig. $1 E$ ), as compared with the control animals. These observations on the regulation of IDX-1 in vivo support the findings obtained from studies of $\beta$-cell lines in vitro $(3,7,8)$. The alterations in the expression levels of the transcription factors $\mathrm{C} / \mathrm{EBP} \beta$ and IDX-1, as assessed by semiquantitative immunocytochemistry, were accompanied by changes in the cellular protein levels of insulin. The islets of the fully diabetic $f a / f a$ animals at the age of 12 wk showed a marked decrease in the fluorescence signal for cellular insulin (Fig. 1, $E$ and $F$ ), reflecting the reduction of the cellular insulin content in $f a / f a$ animals at 12 wk of age (37). Notably the relative cellular insulin levels as measured by fluorescence immunocytochemistry (Fig. $1 F$ ) were discordant from the serum insulin levels in the homozygous Zucker rats (Table I). Whereas $\mathrm{fa} / \mathrm{fa}$ rats had significant hyperinsulinemia at both 7 and $12 \mathrm{wk}$ of age, the average fluorescent intensity for insulin in the islets at 7 wk of age was not significantly higher than in control animals (Fig. $1 F$ ) supporting the existence of relative insulin hypersecretion in response to the increased demand based on insulin resistance leading to relative depletion of insulin stores, but balanced maintenance of replenishment. In contrast, in 12wk-old $f a / f a$ rats, the fluorescent intensity for insulin was markedly diminished (Fig. 1, $E$ and $F$ ), although these animals still exhibited hyperinsulinemia (Table I), providing evidence for the inability of the $\beta$ cells to maintain a constant insulin storage pool at this stage. These findings underscore the dysregulation of $\beta$ cell function at this stage in the development of diabetes mellitus and support earlier findings showing overlapping features of $\beta$ cell hypersecretion in response to insulin resistance and impaired insulin production and storage that have been reported in the Zucker diabetic fatty rat and other hyperglycemic animal models (37).

The upregulation of $\mathrm{C} / \mathrm{EBP} \beta$ and downregulation of IDX-1 in pancreatic islets of Zucker diabetic fatty $(f a / f a)$ rats at the protein level was further confirmed by Western immunoblot analysis of islet whole cell extracts, prepared from 9-wk-old Wistar control rats, heterozygous $(f a /+)$ lean littermates and homozygous ( $f a / f a$ ) Zucker rats (Fig. 2). Status of glucose homeostasis, as reflected by fed serum glucose and plasma insulin levels, are indicated. At the age of $9 \mathrm{wk}$, the Wistar and $(\mathrm{fa} /+)$ control rats exhibited normal body weights, normoglycemia and normoinsulinemia, whereas the $(f a / f a)$ rats showed the expected hyperinsulinemia and hyperglycemia. Notably, at this age $\mathrm{C} / \mathrm{EBP} \beta$ was already markedly upregulated, as analyzed by Western blotting. In contrast to the definitive downregulation of IDX-1 expression in islets of $(f a / f a)$ rats at the age of 12 wk observed in the semiquantitative fluorescent immunocytochemistry (Fig. $1 F$ ), Western immunoblotting still reveals marked expression of IDX-1 protein at the age of $9 \mathrm{wk}$. This circumstance may indicate different time courses for the regulation of the two transcription factors during the development of diabetes in this animal model. The upregulation of C/EBP $\beta$ and the downregulation of IDX-1 and insulin at the protein level appears to be strongly associated with hyperglycemia in this in vivo model for type 2 diabetes. 

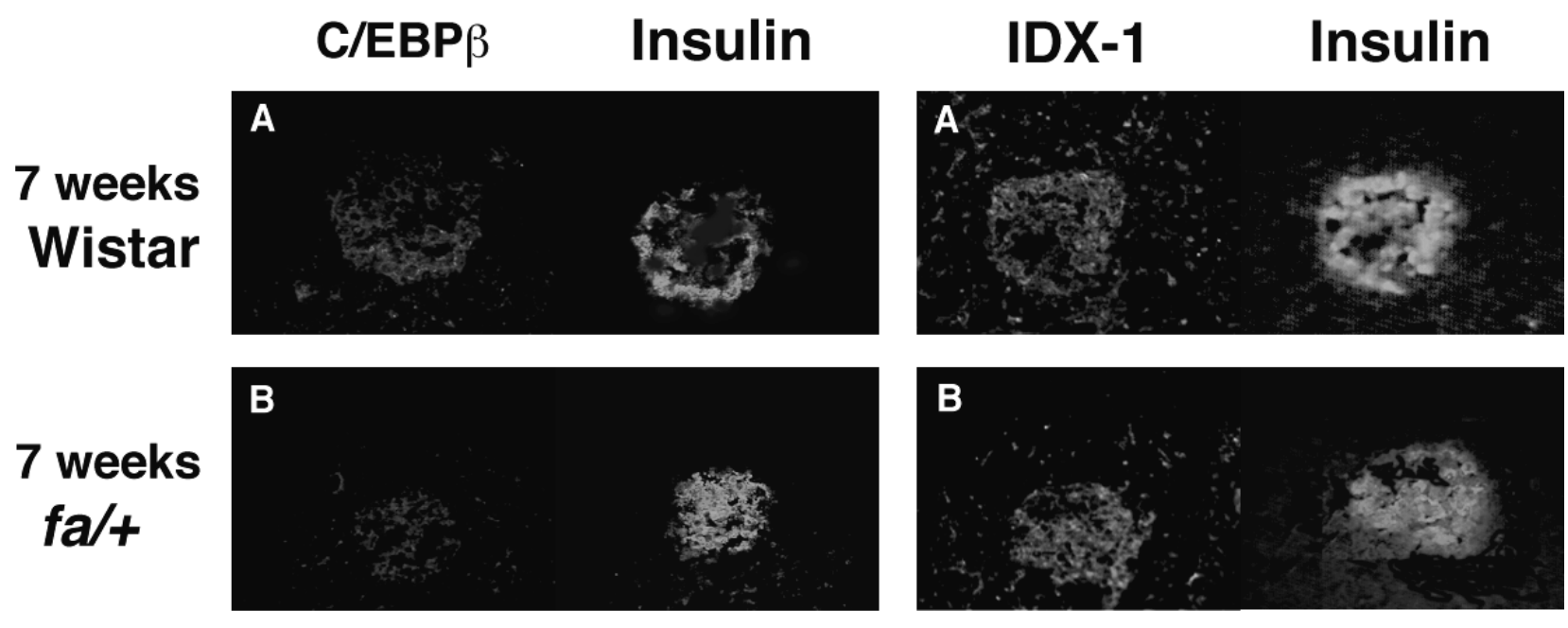

\section{7 weeks $\mathrm{fa} / \mathrm{fa}$}
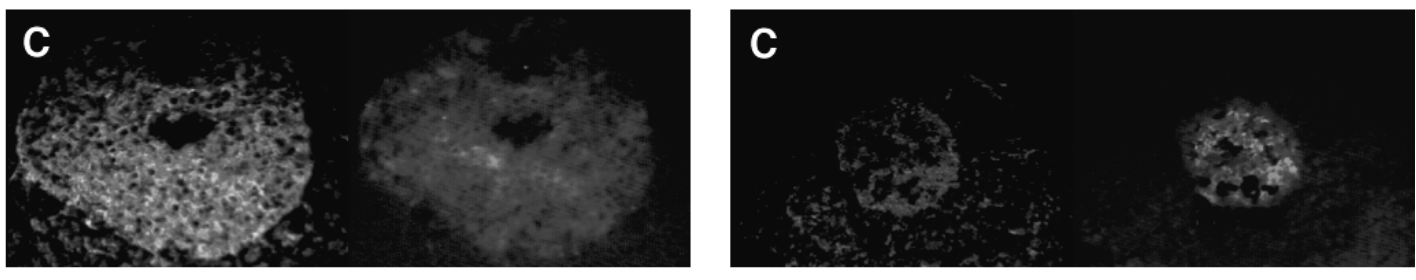

12 weeks $\mathrm{fa} / \mathrm{t}$
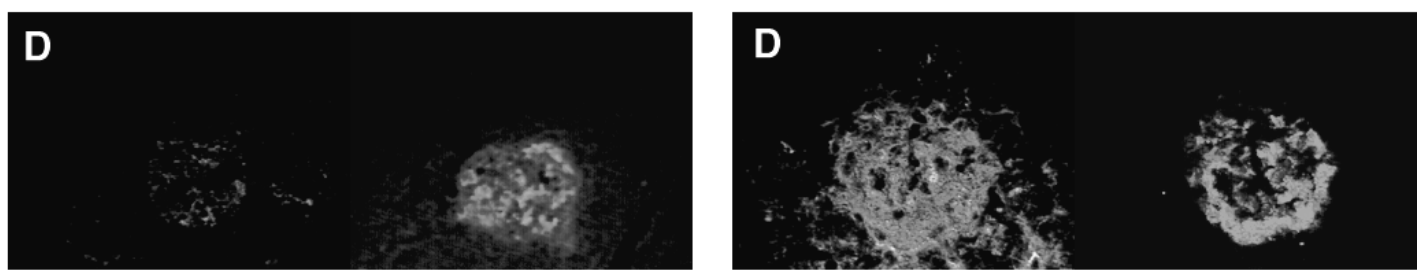

\section{2 weeks $\mathrm{fa} / \mathrm{fa}$}
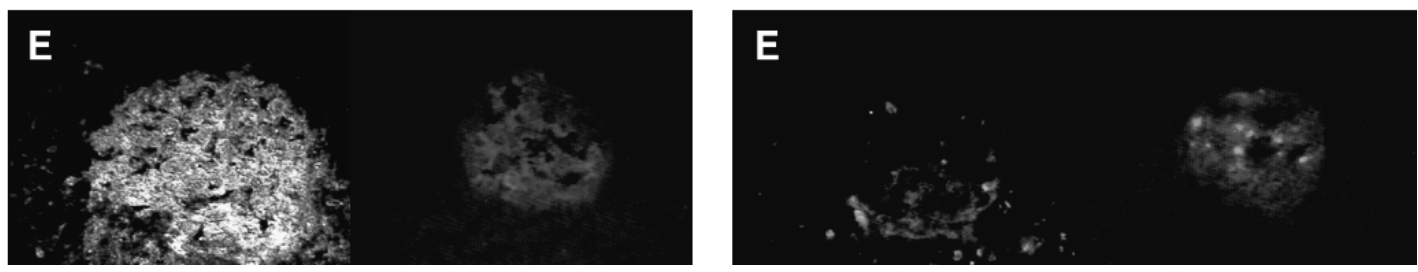

$\mathbf{F}$

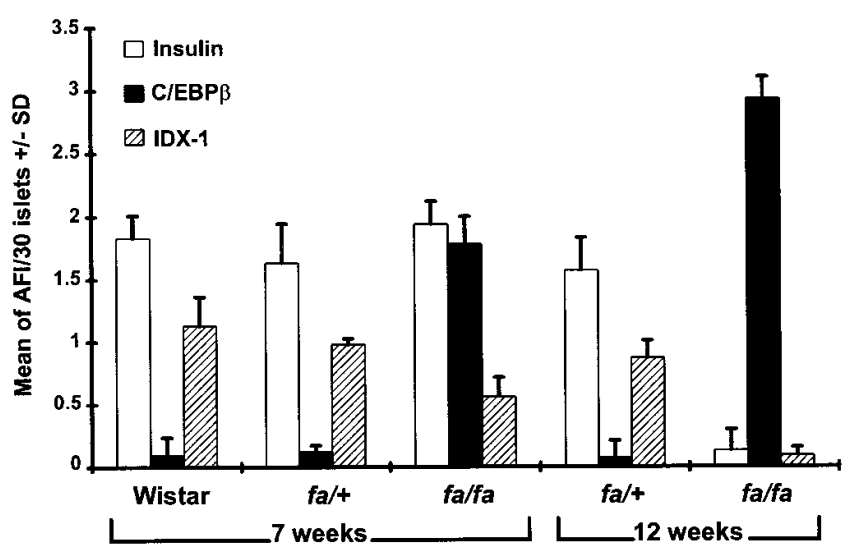

Expression of $C / E B P \beta$ and IDX-1 in pancreatic islets of Zucker diabetic fatty $(\mathrm{fa} / \mathrm{fa})$ rats is regulated at the $\mathrm{mRNA}$ level. To determine whether, during the development of diabetes in the $f a / f a$ rat, $\mathrm{C} / \mathrm{EBP} \beta$ and IDX-1 are mainly regulated
Figure 1. Fluorescence immunocytochemistry for C/EBP $\beta$, IDX-1, and insulin on pancreatic sections of Zucker diabetic $(f a / f a)$ rats, Zucker lean littermates $(f a /+)$, and Wistar control animals; semiquantitative analysis of relative protein levels. Serial $5-\mu \mathrm{m}$ pancreas sections were stained with antisera to $\mathrm{C} / \mathrm{EBP} \beta$ or IDX-1 (Cy3) and insulin (DTAF). Representative sections are shown for $(A)$ Wistar rats, $(B)$ 7-wk-old $(f a /+),(C)$ 7-wk-old $(f a / f a),(D)$ 12-wk-old $(f a /+)$, and $(E)$ 12-wk-old $(f a / f a)$ rats. A marked rise in fluorescence for $\mathrm{C} / \mathrm{EBP} \beta$ is demonstrated in the sections of homozygous animals at $7 \mathrm{wk}$ and more pronounced at 12 wk. $(F)$ Fluorescence intensity values. The average fluorescent intensity was determined for 10 islets per tissue section and three tissue sections per animal, for three animals in each group, and was normalized to fluorescent background. Values are given in means; error bars represent the $\mathrm{SD}$.

by way of translational mechanisms or at the transcriptional level, we compared steady state amounts of mRNA in the islets of control and $f a / f a$ animals. A semiquantitative competitive assay using RT-PCR was established for the quantitation 


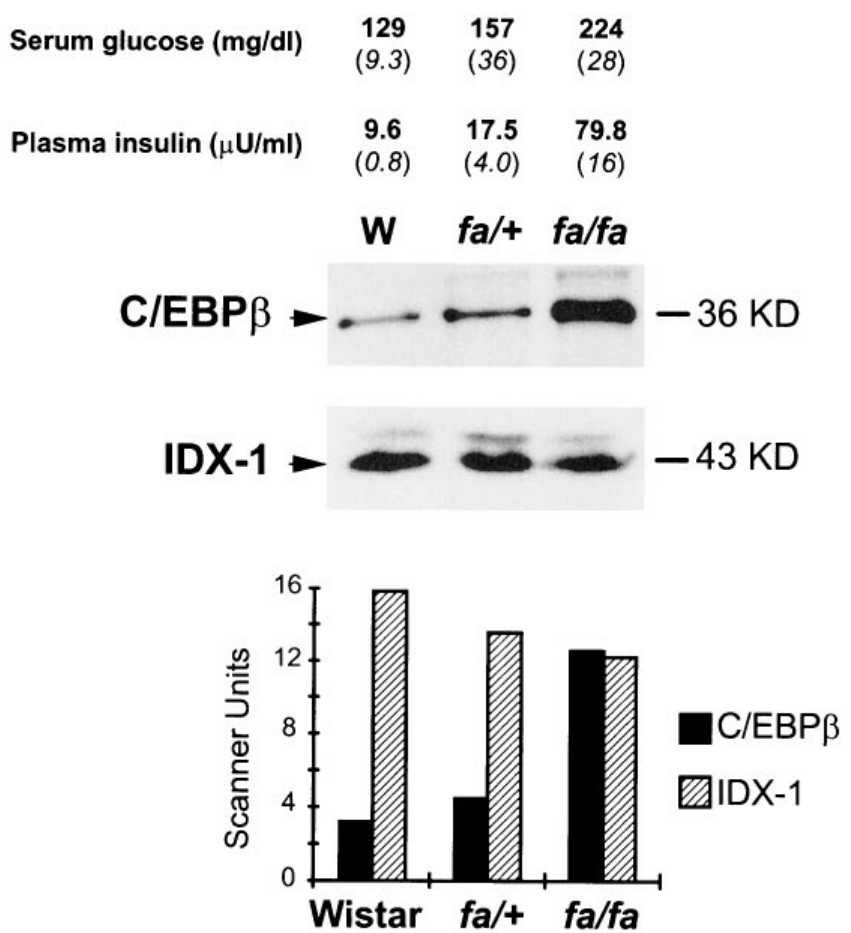

Figure 2. Western immunoblot analysis for $\mathrm{C} / \mathrm{EBP} \beta$ and IDX-1 on pancreatic islets of 9-wk-old Wistar rats, Zucker lean littermates $(f a /+)$, and Zucker diabetic ( $f a / f a)$ rats. Whole cell extracts of pancreatic islets from 9-wk-old animals were analyzed by immunoblotting. Parameters of serum glucose and plasma insulin (top) are fed values and represent the average of $n=5$ animals per group \pm SEM (parentheses). The graph depicts the densitometric quantitation of the immunoblot.

of the very small amounts of RNA that can be extracted from pancreatic islets. Fig. 3 shows the results of mRNA quantitation obtained by RT-PCR for C/EBP $\beta$, IDX-1 and insulin in total RNA isolated from islets of 9-wk-old Wistar rats, $f a /+$ and $f a / f a$ Zucker rats, representing the same animals for which the data of the Western immunoblotting analysis are shown in Fig. 2. Upregulation of the mRNA for C/EBP $\beta$ and downregulation of IDX-1 mRNA in $f a / f a$ animals reveals that the expression of both DNA-binding proteins during the develop- ment of diabetes in this animal model is regulated by mechanisms affecting either gene transcription or mRNA stability.

Expression of $C / E B P \beta$ in the animal model of $90 \%$ pancreatectomy. Because of the possibility that the upregulation of $\mathrm{C} / \mathrm{EBP} \beta$ and downregulation of IDX-1 and insulin in pancreatic $\beta$ cells during the development of diabetes might be attributable to the unique genetic background of the Zucker diabetic fatty rat model, and not generally attributable to sustained supraphysiological glucose levels, we examined an animal model of nongenetically determined diabetes mellitus. We chose the well-studied rat model of partial pancreatectomy (42) for analysis of steady state mRNA levels encoding these proteins in pancreatic islets by quantitative RT-PCR. The animals underwent $90 \%$ pancreatectomy (Px), which induced the development of diabetes mellitus due to insulin deficiency starting around two weeks after the operation (Table II). Sham operated (Sham) and unoperated (unopened) animals were used as controls. RT-PCR analysis was performed at 1, 2, and $4 \mathrm{wk}$ after surgery. Table II shows the body weights and blood glucose levels of the animals that underwent surgery, as well as the control sham-operated and unopened animals. On average the operated animals had the same rate of weight gain as the sham-operated or unopened rats. Hyperglycemia developed by $2 \mathrm{wk}$ after the operation and increased further at $4 \mathrm{wk}$. Sham operated and unopened rats maintained normoglycemia. Similar to the Zucker diabetic fatty rat model, only the animals that were hyperglycemic displayed an upregulation of $\mathrm{C} / \mathrm{EBP} \beta \mathrm{mRNA}$ after $2 \mathrm{wk}$ and a more pronounced elevation after $4 \mathrm{wk}$ after partial pancreatectomy (Fig. $4 A$ ). This upregulation of $\mathrm{C} / \mathrm{EBP} \beta$ was accompanied by a downregulation of IDX-1 and insulin (Fig. 4, $B$ and $C$ ), indicating that high glucose concentrations may predominantly affect the steady state levels of mRNAs of these transcription factors in pancreatic $\beta$ cells. Thus similar findings of regulation of $\mathrm{C} / \mathrm{EBP} \beta$ and IDX-1 expression at the mRNA levels were obtained in both the iatrogenic rat model of $90 \%$ pancreatectomy and the genetically determined Zucker diabetic fatty rat model. In addition, these changes in the regulation of the transcription factors are followed by a downregulation of insulin mRNA. The findings further demonstrate the effectiveness of supraphysiological glucose levels to alter gene expression in vivo in pancreatic $\beta$ cells, and extend the basis for the glucotoxic influence to the level of gene regulation.

Table II. Characteristics of Non-operated Rats (Unopened) and Rats after 90\% Pancreatectomy (Px) or Sham Operation at Time Points Preoperative, 1, 2, and 4 Wk after Surgery

\begin{tabular}{|c|c|c|c|c|}
\hline Time point & Preop. & $1 \mathrm{Wk}$ & $2 \mathrm{Wk}$ & $4 \mathrm{Wk}$ \\
\hline \multicolumn{5}{|c|}{ Body weight (g) } \\
\hline$P x$ & $106.9 \pm 8.4(17)$ & $145.0 \pm 10.1$ & $182.0 \pm 6.3(8)$ & $287.5 \pm 4.4(5)$ \\
\hline Sham & $108.2 \pm 6.5(10)$ & $151.0 \pm 7.2(3)$ & $226.8 \pm 8.3(4)$ & $289.7 \pm 2.1(3)$ \\
\hline Unopened & $98.5 \pm 1.9(4)$ & & & $298.0 \pm 39.9(4)$ \\
\hline \multicolumn{5}{|c|}{ Glucose $(\mathrm{mg} / \mathrm{dl})$} \\
\hline$P x$ & $86.5 \pm 8.4(17)$ & $96.0 \pm 16.8(4)$ & $175.0 \pm 42.7(8)$ & $264.0 \pm 30.5(5)$ \\
\hline Sham & $80.2 \pm(10)$ & $84.0 \pm 7.0$ & $91.5 \pm 23.5$ (4) & $127.3 \pm 30.9$ \\
\hline Unopened & $86.3 \pm(4)$ & & & $83.0 \pm 8.3(4)$ \\
\hline
\end{tabular}

Parameters for glucose represent fasted values. Parameters represent the average \pm SEM. Parameters in parentheses represent the number of animals in each group. 

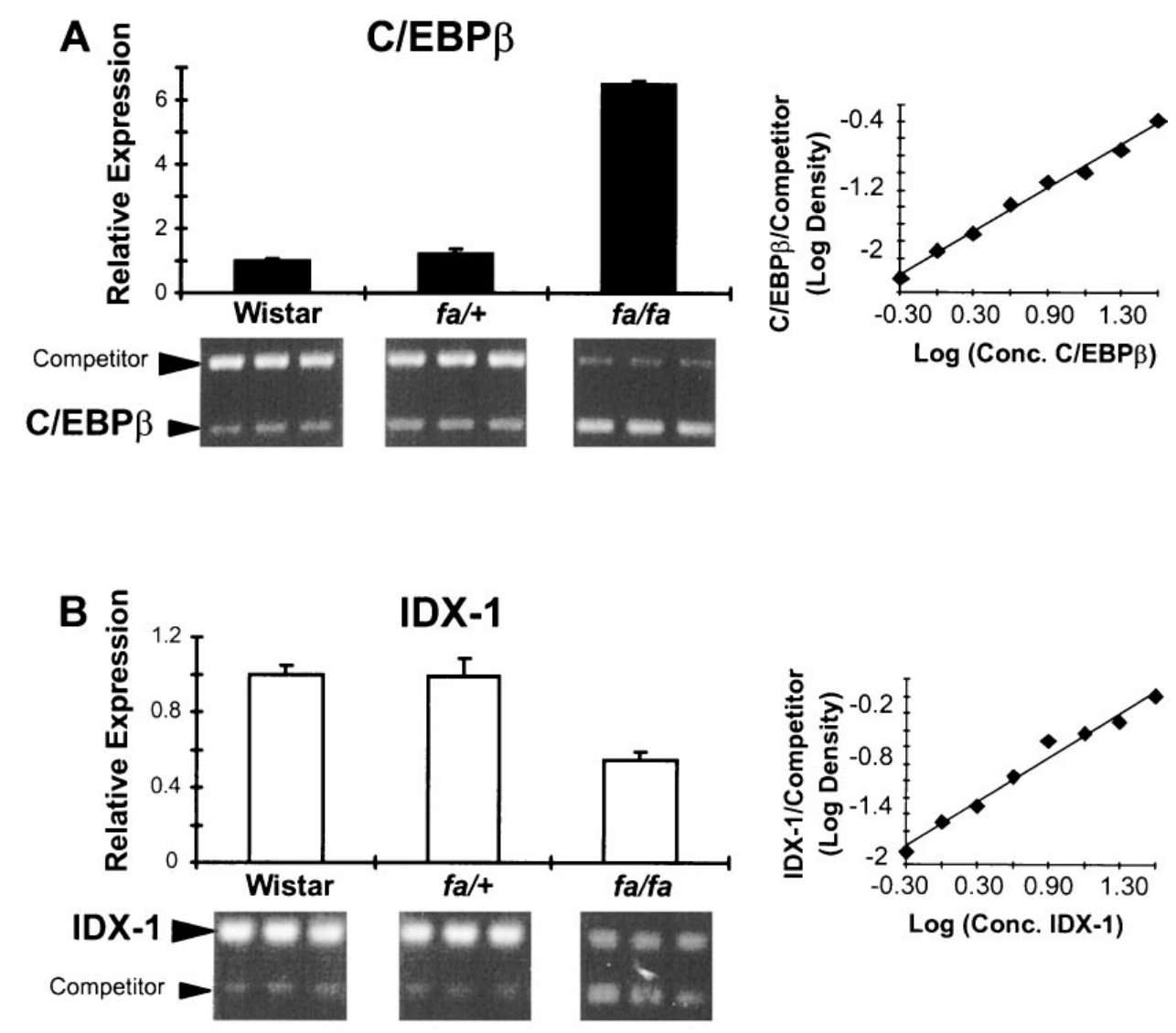

Figure 3. Semiquantitative competitive RT-PCR for C/EBP $\beta$, IDX-1, and insulin mRNA from islets of 9-wk-old Wistar rats, Zucker lean littermates $(f a /+)$, and Zucker diabetic $(f a / f a)$ rats. Total RNA from pooled islet preparations of each group were reverse transcribed in triplicate and identical amounts of cDNAs were subjected to PCR Each reaction contained equal amounts of competitor templates, which were designed to be amplified by the same primer oligonucleotides as the target sequences. The intensity of the bands of the target sequence was quantitated in relation to the competitor. Values are presented as relative expression calculated from the means of the triplicate samples in each group. The error bars represent SEM. The insert plots denote the comparison of the effectiveness of amplification of target and competitor sequences. All competitors displayed almost identical amplification kinetics as the target sequences. $\mathrm{C} / \mathrm{EBP} \beta$ mRNA is upregulated in the islets of hyperglycemic $(f a / f a)$ animals $(A)$. This is accompanied by a downregulation of IDX-1 $(B)$ and insulin mRNA $(C)$.

\section{Discussion}

Type 2 diabetes is characterized by a gradual deterioration of $\beta$ cell function leading to both an impairment in glucose-stimulated insulin secretion and a degranulation of $\beta$ cells (43). This phenomenon has been attributed to the influence of chronic hyperglycemia and the ensuing metabolic alterations that occur in the diabetic state, thereby preventing the $\beta$ cells from maintaining their physiological response. According to the concept of glucotoxicity, a sustained elevated glucose level in and of itself is believed to exert deleterious effects on pancreatic $\beta$ cells (1). In fact, impaired $\beta$ cell function has been demonstrated in several model systems in which $\beta$ cells were ex- posed to high glucose levels $(5,44-46)$. At the cellular level sustained high glucose alters insulin biosynthesis as well as insulin secretion (47). More recently a downregulation of insulin mRNA by high glucose concentrations was demonstrated suggesting an effect of high glucose on insulin gene expression. This effect of glucose on insulin mRNA levels has been proposed to be mediated by transcription factors acting on the promoter of the insulin gene (6-8). In addition to the reported downregulation of the insulin gene transactivators IDX-1 and RIPE3b1-binding proteins by high glucose, we described earlier a glucose stress-mediated upregulation of $\mathrm{C} / \mathrm{EBP} \beta$ that acts as a transcriptional repressor of insulin gene transcription (10). We observed an upregulation of $\mathrm{C} / \mathrm{EBP} \beta$ in vitro in cul- 
A

\section{C/EBP $\beta$}
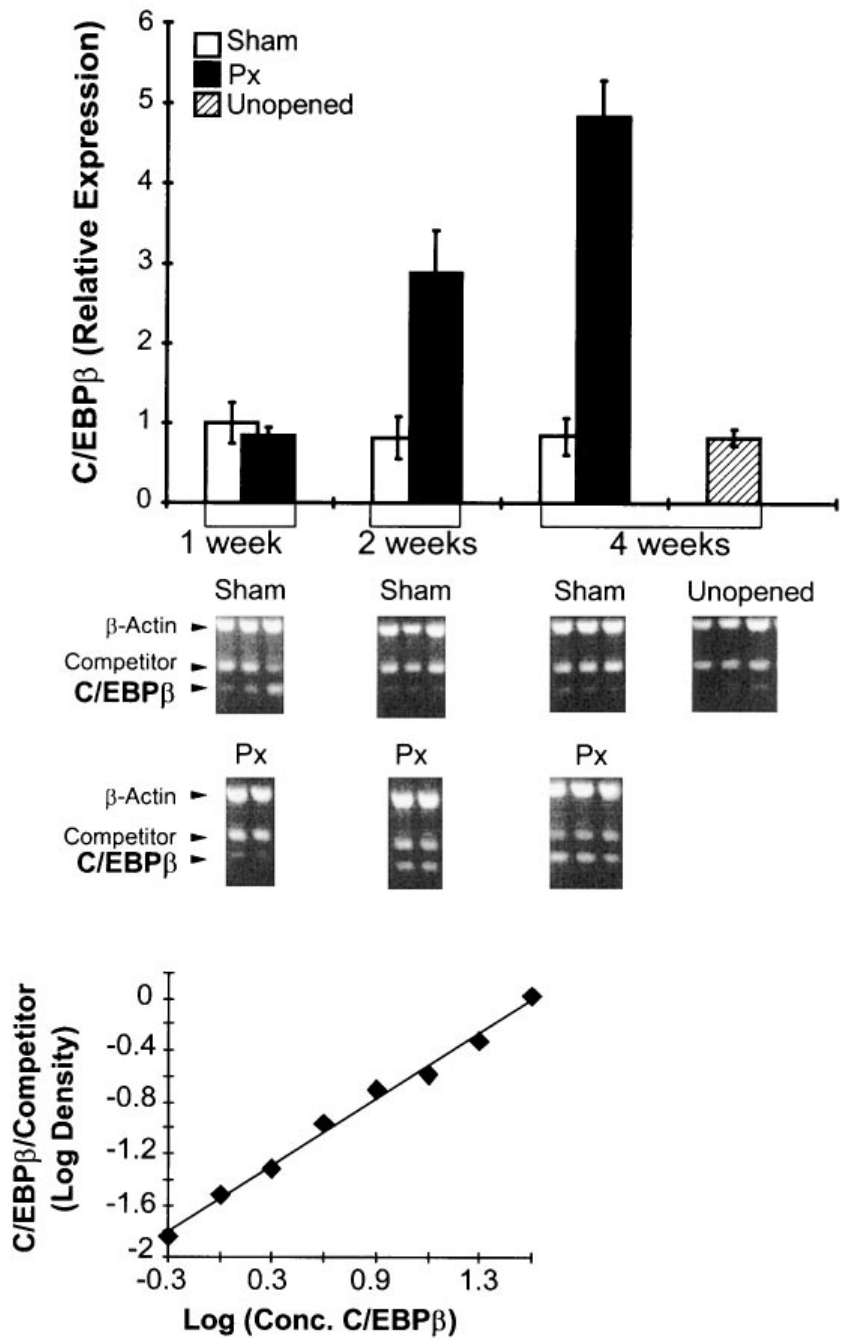
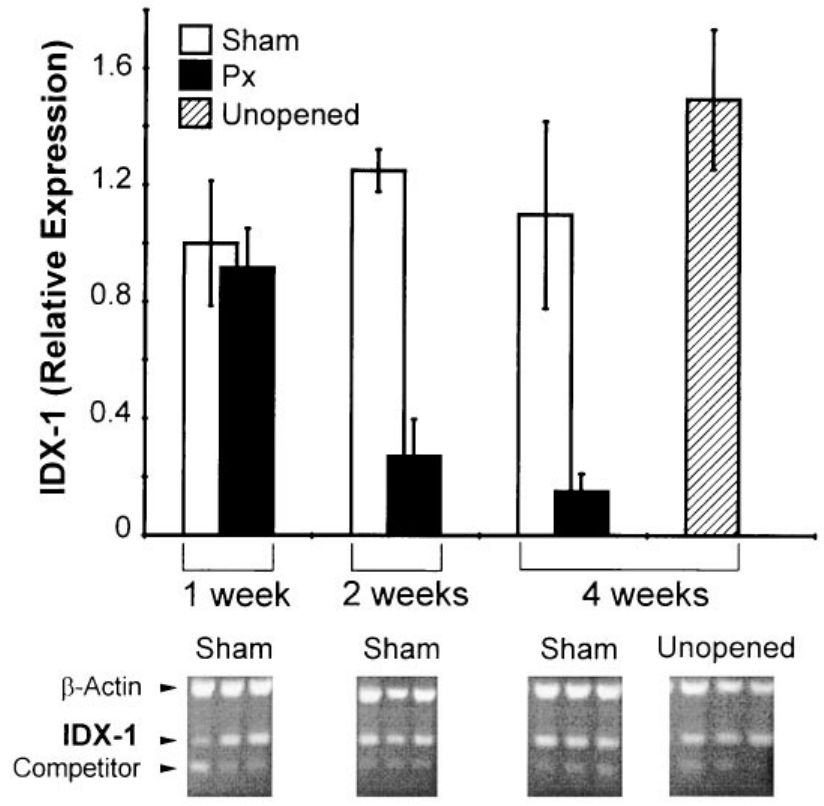

$\mathrm{Px}$

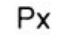

$\mathrm{Px}$
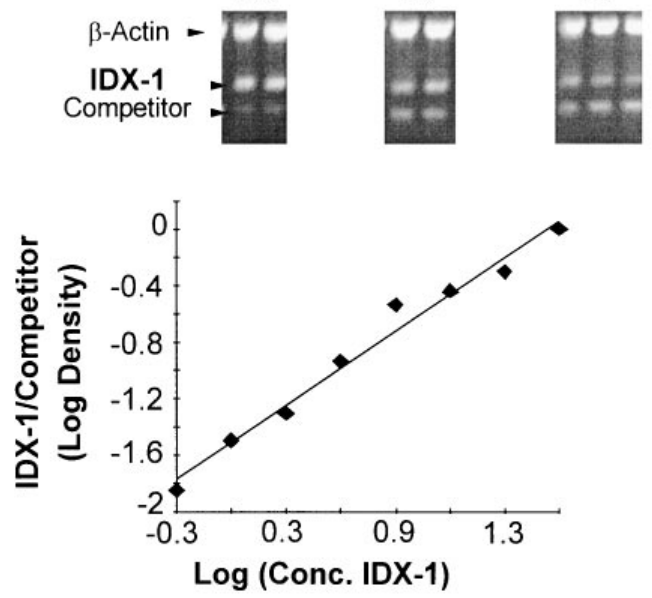

Figure 4. Semiquantitative competitive RT-PCR for C/EBP $\beta$, IDX-1, and insulin RNA from islets of $90 \%$ pancreatectomized rats. Total RNA from pooled islet preparations of each group were reverse transcribed in duplicate or triplicate and equal amounts subjected to PCR. Each reaction contained equal amounts of competitor templates, which were designed to be amplified by the same primer oligonucleotides as the target sequences. In addition, each reaction contained primer oligonucleotides for amplification of endogenous $\beta$-actin mRNA as a loading control. The intensity of the bands of the target sequence was quantitated in relation to the competitor and this relation normalized to the intensity of the $\beta$-actin band. Values are presented as relative expression calculated from the means of the triplicate samples in each group, whereby the values of sham-operated animals $1 \mathrm{wk}$ after pancreatectomy were set to one. The error bars represent SEM. The insert graphs denote the comparison of the effectivity of amplification of target and competitor sequences. All competitors displayed almost identical amplification kinetics as the target sequences. $\mathrm{C} / \mathrm{EBP} \beta$ is upregulated in the hyperglycemic animals at 2 and $4 \mathrm{wk}$ after surgery $(A)$. This is accompanied by a downregulation of IDX-1 mRNA $(B)$, and insulin mRNA $(C)$.

tured pancreatic $\beta$ cell lines upon exposure to high glucose levels suggesting a role for $\mathrm{C} / \mathrm{EBP} \beta$ in mediating the inhibition of insulin gene transcription during the metabolic stress conferred by hyperglycemia.

It is worth noting that all of the experiments performed so far on the regulation of transcription factor expression in response to glucotoxicity have been done in vitro, mostly using transformed insulinoma cells that are poorly responsive to glu- cose. In the studies using HIT cells, several weeks of passage were required to manifest changes in IDX-1 levels raising the possibility that clonal selection could take place. Therefore we examined the roles of $\mathrm{C} / \mathrm{EBP} \beta$ and IDX-1 in vivo and provide evidence for the implication of both of these transcription factors in the pathogenesis of diabetes mellitus.

The Zucker diabetic fatty (ZDF) rat is a well-established animal model of obesity and diabetes in which the metabolic 
C
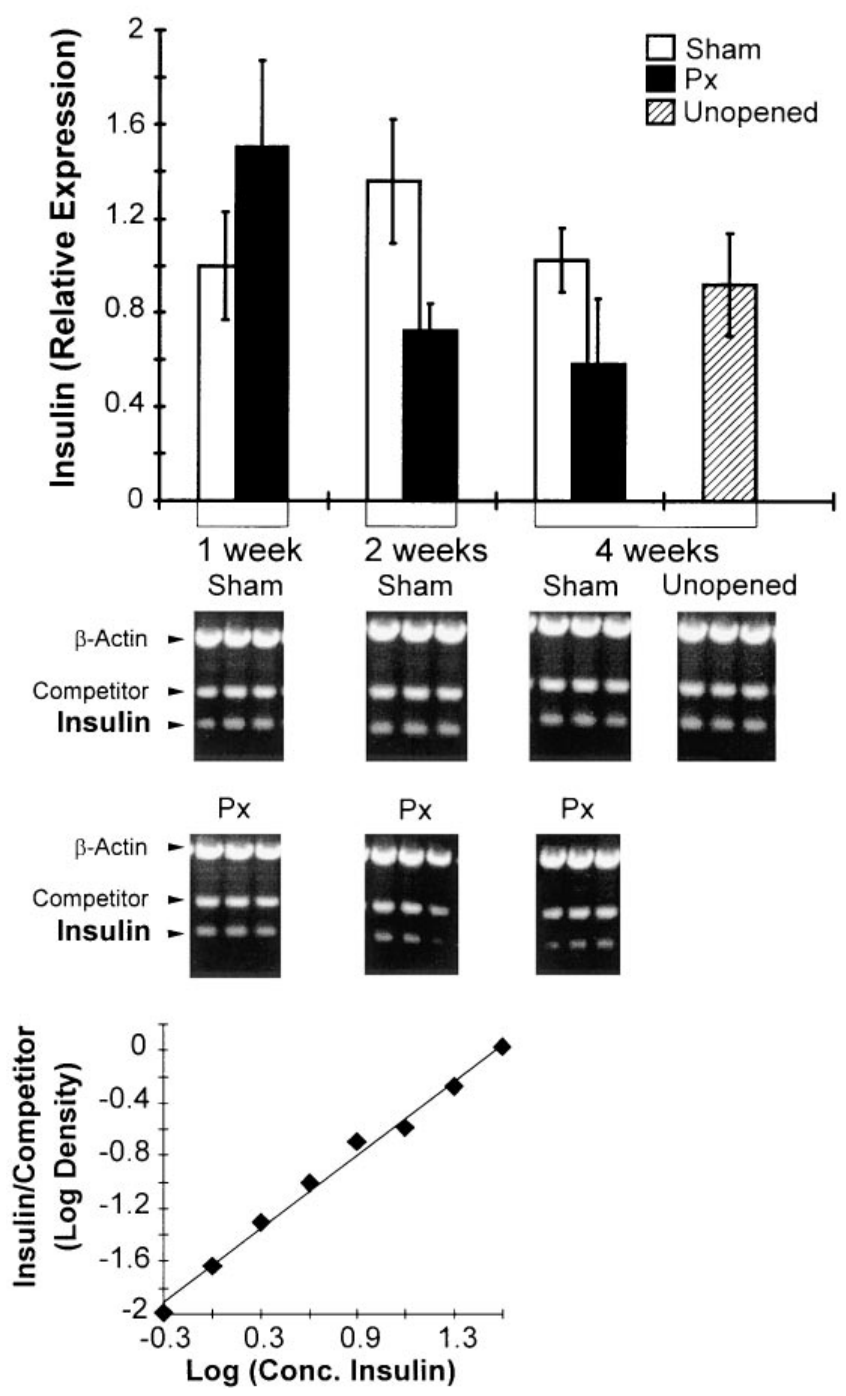

Figure 4 (Continued)

alterations have been characterized extensively (37). Recently, the genetic defect of the ZDF rat was mapped to a point mutation within the receptor for the obesity protein (leptin) resulting in an impairment of leptin receptor signaling (38-40). Although the ZDF rat model has limitations when examining the genetic basis responsible for the development of type 2 diabetes, the metabolic sequelae and phenotypic features resemble those manifested in human non-insulin-dependent diabetes mellitus. In particular a prediabetic interval occurs during the development of obesity, in which hyperinsulinemia and moderately impaired glucose tolerance (5-6 wk of age) can be distinguished from fully-developed diabetes with marked hyperglycemia and impaired insulin secretion at an older age (12-18 wk). The finding of a marked upregulation of C/EBP $\beta$ and a downregulation of IDX-1 in the islets of these ZDF animals in the course of the evolution of the onset of diabetes and later fully developed diabetic state suggests a potentially im- portant role of both transcription factors in promoting alterations of gene expression in pancreatic $\beta$ cells in response to changes in serum glucose concentrations. Furthermore, our data in the ZDF rat model confirm previous findings in this model showing a downregulation of insulin gene expression during the course of the development of the diabetic state despite the initial persistence of hyperinsulinemia (37). In addition it has been shown that the insulin content of the islets is markedly decreased in the diabetic ZDF rats at $12 \mathrm{wk}$ of age. This obvious contradiction, however, can be explained by the strong increase in the number of $\beta$ cells per islet (islet hyperplasia) in the diabetic ZDF rats (37). The increased mass of $\beta$ cells maintains the hyperinsulinemia necessary to counteract the peripheral insulin resistance that is present in these animals despite the decrease of insulin gene expression, insulin biosynthesis and insulin content within the single $\beta$ cell.

To determine whether the upregulation of $\mathrm{C} / \mathrm{EBP} \beta$ and downregulation of IDX-1 in pancreatic $\beta$ cells is a unique feature of the ZDF rats, we examined the $90 \%$ pancreatectomy rat as another well established model of diabetes. In this model elevated glucose levels are a prerequisite for the evolution of $\beta$ cell dysfunction (48). By demonstrating the regulation of both transcription factors at the mRNA level in vivo $2-4 \mathrm{wk}$ after partial pancreatectomy, we defined high glucose levels as a major factor driving transcription, and provide evidence that the findings obtained from the ZDF rat model may be more generally applicable to the pathogenesis of the development of diabetes.

In addition to the documented deleterious effects of supraphysiological glucose levels on $\beta$ cell function there is a growing body of evidence that high serum lipid levels and in particular fat accumulation in the islets may play a role in altering $\beta$ cell function during the development of diabetes mellitus, so called lipotoxicity $(49,50)$. Exposure of pancreatic islets to fatty acids (FFA) inhibits glucose-induced insulin secretion and biosynthesis in vitro and in vivo $(14,51)$ and specific LDL binding and uptake by pancreatic islet $\beta$ cells has been demonstrated recently (52). In contrast, low levels of free FFA are proposed as a signal from the adipose tissue to the pancreatic $\beta$ cell to increase insulin secretion in response to rising insulin resistance (53). This mechanism was reported to be defective in islets of ZDF rats (13), which are defective in leptin signaling. The accumulation of triglycerides during the development of diabetes in ZDF rat islets is associated with impaired insulin biosynthesis and secretion. This has been attributed to enhanced intracellular esterification and reduced oxidation of FFA in the islets because of the lack of leptin signaling (54, 55). Consequently, reconstituting leptin effects in islets of ZDF rats reverses the diabetogenic phenotype by reducing the formation of triglycerides from FFA and restoring the response of insulin gene transcription to low levels of FFA $(56,57)$. In contrast, overexpression of leptin by adenovirus mediated gene transfer in normal rats leads to complete disappearance of body fat (58) and depletion of FFA and triglycerides from pancreatic islets (59), which also causes impaired $\beta$ cell function.

The $\beta$ cell dysfunction associated with defective leptin signaling in ZDF rats has been attributed to the stimulation of nitric oxide production via induction of the inducible form of nitric oxide synthase by FFA (60); a mechanism which is similar to the effects of IL- $1 \beta$ in pancreatic islets. This notion is supported by the finding that the depletion of islet triglyceride 
stores by leptin or troglitazone treatment leads to resistance of $\beta$ cells to IL-1 $\beta$ induced cytotoxicity (61).

More recently, a decrease in IDX-1 associated with a reduced expression of insulin, glucokinase and glucose transporter type 2 was reported in rat pancreatic islets upon exposure to palmitic acid in vitro. These effects were dependent on mitochondrial oxidation of the fatty acid (15). These findings imply that lipotoxic effects may also alter islet cell gene expression by affecting the activity of transcription factors regulating these islet genes.

Our data obtained from the rat model of $90 \%$ pancreatectomy, and earlier from insulinoma cell lines, provide strong evidence that glucose is a major regulator of the expression of both IDX- 1 and $\mathrm{C} / \mathrm{EBP} \beta$ in pancreatic $\beta$ cells. It has been reported that $\beta$ cell dysfunction antedates the development of overt hyperglycemia and coincides with the onset of hyperlipidemia in the ZDF rat model (37). Thus, in this animal, model lipotoxic effects may already contribute to a dysregulation of transcription factors which control $\beta$ cell gene transcription before the development of hyperglycemia. A more detailed analysis of the time courses of the expression of C/EBP $\beta$ and IDX-1 during the development of diabetes in different diabetic animal models may provide evidence for this circumstance. Additional studies will be required to determine the relative contributions of glucotoxicity versus lipotoxicity (if any) to the alterations of $\beta$ cell functions in the partial pancreatectomy diabetic rat.

Based on our current knowledge of the function of $\mathrm{C} / \mathrm{EBP} \beta$ and IDX-1 in pancreatic $\beta$ cells, we can not yet determine the relative contributions of the two proteins to the impaired insulin gene expression in diabetes mellitus. Recent in vitro data, however, suggest that transactivation of the insulin gene promoter by IDX-1 may only be partially responsible for the overall transcriptional activity of this promoter in pancreatic $\beta$ cells (9). In studies in which the hamster insulinoma cell line HIT-T15 was cultured chronically in high glucose levels and consequently backshifted to low glucose levels, the decreased insulin gene expression seen in high glucose was restored despite the persistence of lowered levels of IDX-1. Moreover, when the expression of IDX- 1 in the $\beta$ cell line MIN6 was suppressed by antisense oligonucleotides down to a level of $14 \%$ of control, no decrease in insulin mRNA was detected (62). Although these findings may be specific to the model systems of clonal cell lines and are not necessarily applicable to the in vivo situation, they suggest the involvement of other transcription factors in the glucotoxic alterations of insulin gene transcription. In addition to the potential involvement of RIPE3b1-binding proteins (7), $\mathrm{C} / \mathrm{EBP} \beta$, which is induced by the metabolic stress of supraphysiological glucose levels in pancreatic $\beta$ cells, may serve as a transcription factor with potential implications in the dysregulation of insulin gene expression in diabetes. Clearly, insulin gene transcription is regulated in a complex manner and other transcription factors are likely to be involved as well.

In addition to the regulation of insulin gene transcription, IDX-1 transactivates the promoters of other genes in pancreatic $\beta$ cells, such as the genes for glucokinase, islet amyloid polypeptide, and glucose transporter type 2 (63-65). Moreover, IDX-1 expression is associated with both the development and the maintenance of $\beta$ cell phenotype $(66,67)$. Recently, an inactivating mutation in the IDX-1 gene has been linked to pancreas development and diabetes mellitus (68). A child homozygous for the mutation was born without a pan- creas (pancreatic agenesis; reference 67). Heterozygous carriers of the mutation develop early onset diabetes (MODY4; reference 68). Therefore the loss of IDX-1 expression during the development of diabetes mellitus in vivo may lead to impaired pancreatic $\beta$ cell function by affecting cellular events different from insulin gene transcription, such as glucose sensing, glucose metabolism or differentiation status of the pancreatic $\beta$ cell. Similarly, other target genes than the insulin gene for the transcription factor $\mathrm{C} / \mathrm{EBP} \beta$ in the pancreatic $\beta$ cell may be characterized in the future.

Although these studies cannot prove cause and effect, they are consistent with the hypothesis that chronic hyperglycemia, possibly accompanied by lipotoxic effects, resets the levels of transcriptional activators and suppressors of insulin gene expression in $\beta$ cells and thereby contributes to the dysregulated production of insulin in diabetes.

\section{Acknowledgments}

We thank John Latimer for performing pancreatectomy and islet isolation, Dr. S.J. Chan for the Plasmid pRat Ins-1, Karen McManus for the insulin and glucose assays, and Townley Budde for help with preparation of the manuscript.

J. Seufert is supported by the Deutsche Forschungsgemeinschaft (DFG) grant No. 787/1-2. The studies were supported in part by U.S. Public Health Service grants DK30834 (J.F. Habener), DK30457 (J.F. Habener), and DK35449 (G.C. Weir). J.F. Habener is an Investigator with the Howard Hughes Medical Institute.

\section{References}

1. Robertson, R.P., L.K. Olson, and H.J. Zhang. 1994. Differentiating glucose toxicity from glucose desensitization: a new message from the insulin gene. Diabetes. 43:1085-1089.

2. Leahy, J.L., S. Bonner-Weir, and G.C. Weir. 1992. Beta-cell dysfunction induced by chronic hyperglycemia. Current ideas on mechanism of impaired glucose-induced insulin secretion. Diabetes Care. 15:442-455.

3. Olson, L.K., J.B. Redmon, H.C. Towle, and R.P. Robertson. 1993. Chronic exposure of HIT cells to high glucose concentrations paradoxically decreases insulin gene transcription and alters binding of insulin gene regulatory protein. J. Clin. Invest. 92:514-519.

4. Eizirik, D.L., G.S. Korbutt, and C. Hellerstrom. 1992. Prolonged exposure of human pancreatic islets to high glucose concentrations in vitro impairs the beta-cell function. J. Clin. Invest. 90:1263-1268.

5. Leahy, J.L., and G.C. Weir. 1991. Beta-cell dysfunction in hyperglycemic rat models: recovery of glucose-induced insulin secretion with lowering of the ambient glucose level. Diabetologia. 34:640-647.

6. Poitout, V., L.K. Olson, and R.P. Robertson. 1996. Chronic exposure of betaTC- 6 cells to supraphysiologic concentrations of glucose decreases binding of the RIPE3b1 insulin gene transcription activator. J. Clin. Invest. 97:10411046 .

7. Sharma, A., L.K. Olson, R.P. Robertson, and R. Stein. 1995. The reduction of insulin gene transcription in HIT-T15 beta cells chronically exposed to high glucose concentration is associated with the loss of RIPE3b1 and STF-1 transcription factor expression. Mol. Endocrinol. 9:1127-1134.

8. Olson, L.K., A. Sharma, M. Peshavaria, C.V. Wright, H.C. Towle, R.P. Robertson, and R. Stein. 1995. Reduction of insulin gene transcription in HITT15 beta cells chronically exposed to a supraphysiologic glucose concentration is associated with loss of STF-1 transcription factor expression. Proc. Natl. Acad. Sci. USA. 92:9127-9131.

9. Moran, A., H.J. Zhang, L.K. Olson, J.S. Harmon, V. Poitout, and R.P. Robertson. 1997. Differentiation of glucose toxicity from beta cell exhaustion during the evolution of defective insulin gene expression in the pancreatic islet cell line, HIT-T15. J. Clin. Invest. 99:534-539.

10. Lu, M., J. Seufert, and J.F. Habener. 1997. Pancreatic $\beta$-cell specific repression of insulin gene transcription by CCAAT/enhancer-binding protein $\beta$ (C/EBP $\beta$ ): inhibitory interactions with basic helix-loop-helix factor E47. J. Biol. Chem. 272:28349-28359.

11. Olson, L.K., V. Poitout, and R.P. Robertson. 1996. Glucose rapidly and reversibly decreases INS-1 cell insulin gene transcription via decrements in STF-1 and C1 activator transcription factor activity. Mol. Endocrinol. 12:207-219.

12. Zangen, D.H., S. Bonner-Weir, C.H. Lee, J.B. Latimer, C.P. Miller, J.F. 
Habener, and G.C. Weir. 1997. Reduced insulin, GLUT2, and IDX-1 in betacells after partial pancreatectomy. Diabetes. 46:258-264.

13. Hirose, H., Y.H. Lee, L.R. Inman, Y. Nagasawa, J.H. Johnson, and R.H. Unger. 1996. Defective fatty acid-mediated beta-cell compensation in Zucker diabetic fatty rats. Pathogenic implications for obesity-dependent diabetes. $J$. Biol. Chem. 271:5633-5637.

14. Lee, Y., H. Hirose, M. Ohneda, J.H. Johnson, J.D. McGarry, and R.H. Unger. 1994. Beta-cell lipotoxicity in the pathogenesis of non-insulin-dependent diabetes mellitus of obese rats: impairment in adipocyte-beta-cell relationships. Proc. Natl. Acad. Sci. USA. 91:10878-10882.

15. Gremlich, S., C. Bonny, G. Waeber, and B. Thorens. 1997. Fatty acids decrease IDX-1 expression in rat pancreatic islets and reduce GLUT2, glucokinase, insulin, and somatostatin levels. J. Biol. Chem. 272:30261-30269.

16. Philippe, J. 1994. Pancreatic expression of the insulin and glucagon genes: update 1994. Endocr. Rev. 2:21-27.

17. Steiner, D.F., S.J. Chan, J.M. Welsh, and S.C. Kwok. 1985. Structure and evolution of the insulin gene. Annu. Rev. Genet. 19:463-484.

18. Miller, C.P., R.E. McGehee, Jr., and J.F. Habener. 1994. IDX-1: a new homeodomain transcription factor expressed in rat pancreatic islets and duodenum that transactivates the somatostatin gene. EMBO (Eur. Mol. Biol. Organ.) J. 13:1145-1156.

19. Karlsson, O., T. Edlund, J.B. Moss, W.J. Rutter, and M.D. Walker. 1987. A mutational analysis of the insulin gene transcription control region: expression in beta cells is dependent on two related sequences within the enhancer. Proc. Natl. Acad. Sci. USA. 84:8819-8823.

20. Ohlsson, H., and T. Edlund. 1986. Sequence-specific interactions of nuclear factors with the insulin gene enhancer. Cell. 45:35-44.

21. Peers, B., J. Leonard, S. Sharma, G. Teitelman, and M.R. Montminy. 1994. Insulin expression in pancreatic islet cells relies on cooperative interactions between the helix loop helix factor E47 and the homeobox factor STF-1. Mol. Endocrinol. 8:1798-1806.

22. Alam, T., M.R. An, and J. Papaconstantinou. 1992. Differential expression of three C/EBP isoforms in multiple tissues during the acute phase response. J. Biol. Chem. 267:5021-5024.

23. Mandrup, S., and M.D. Lane. 1997. Regulating adipogenesis. J. Biol. Chem. 272:5367-5370.

24. Raught, B., W.S.L. Liao, and J.M. Rosen. 1995. Developmentally and hormonally regulated CCAAT/enhancer-binding protein isoforms influence ß-casein gene expression. Mol. Endocrinol. 9:1223-1232.

25. Muller, C., E. Kowenz-Leutz, S. Grieser-Ade, T. Graf, and A. Leutz. 1995. NF-M (chicken C/EBP beta) induces eosinophilic differentiation and apoptosis in a hematopoietic progenitor cell line. EMBO (Eur. Mol. Biol. Organ.) J. 14:6127-6135.

26. Wedel, A., and H.W. Ziegler-Heitbrock. 1997. The C/EBP family of transcription factors. Immunobiology. 193:171-185.

27. Pei, D.Q., and C.H. Shih. 1990. Transcriptional activation and repression by cellular DNA-binding protein C/EBP. J. Virol. 64:1517-1522.

28. Kava, R., M.R.C. Greenwood, and P.R. Johnson. 1990. Zucker (fa/fa) rat. ILAR News. 32:4-8.

29. Orland, M.J., R. Chyn, and M.A. Permutt. 1985. Modulation of proinsulin messenger RNA after partial pancreatectomy in rats. Relationships to glucose homeostasis. J. Clin. Invest. 75:2047-2055.

30. Fehmann, H.C., and J.F. Habener. 1991. Homologous desensitization of the insulinotropic glucagon-like peptide-I (7-37) receptor of insulinoma (HITT15) cells. Endocrinology. 128:2880-2888.

31. Kieffer, T.J., R.S. Heller, C.G. Unson, G.C. Weir, and J.F. Habener. 1996. Distribution of glucagon receptors on hormone-specific endocrine cells of rat pancreatic islets. Endocrinology. 137:5119-5125.

32. Gotoh, M., T. Maki, S. Satomi, J. Porter, S. Bonner-Weir, C.J. O'Hara, and A.P. Monaco. 1987. Reproducible high yield of rat islets by stationary in vitro digestion following pancreatic ductal or portal venous collagenase injection. Transplantation (Baltimore). 43:725-730.

33. Chomczynski, P., and N. Sacchi. 1987. Single-step method of RNA isolation by acid guanidinium thiocyanate-phenol-chloroform extraction. Anal. Biochem. 162:156-159.

34. Ron, D., and J.F. Habener. 1992. CHOP, a novel developmentally regulated nuclear protein that dimerizes with transcription factors C/EBP and LAP and functions as a dominant-negative inhibitor of gene transcription. Genes Dev. 6:439-453.

35. Chan, S.J., B.E. Noyes, K.L. Agarwal, and D.F. Steiner. 1979. Construction and selection of recombinant plasmids containing full-length complementary DNAs corresponding to rat insulins I and II. Proc. Natl. Acad. Sci. USA. 76:5036-5040.

36. Zimmermann, K., and J.W. Mannhalter. 1996. Technical aspects of quantitative competitive PCR. Biotechniques. 21:268-279.

37. Tokuyama, Y., J. Sturis, A.M. DePaoli, J. Takeda, M. Stoffel, J. Tang, X. Sun, K.S. Polonsky, and G.I. Bell. 1995. Evolution of beta-cell dysfunction in the male Zucker diabetic fatty rat. Diabetes. 44:1447-1457.

38. Iida, M., T. Murakami, K. Ishida, A. Mizuno, M. Kuwajima, and K. Shima. 1996. Substitution at codon 269 (glutamine $\rightarrow$ proline) of the leptin receptor (OB-R) cDNA is the only mutation found in the Zucker fatty ( $f a / f a)$ rat. Biochem. Biophys. Res. Commun. 224:597-604.
39. Phillips, M.S., Q. Liu, H.A. Hammond, V. Dugan, P.J. Hey, C.J. Caskey, and J.F. Hess. 1996. Leptin receptor missense mutation in the fatty Zucker rat. Nat. Genet. 13:18-19.

40. Takaya, K., Y. Ogawa, N. Isse, T. Okazaki, N. Satoh, H. Masuzaki, K. Mori, N. Tamura, K. Hosoda, and K. Nakao. 1996. Molecular cloning of rat leptin receptor isoform complementary DNA's identification of a missense mutation in Zucker fatty (fa/fa) rats. Biochem. Biophys. Res. Commun. 225:75-83.

41. White, D.W., Y. Wang, S.C. Chua, J.P. Morgenstern, R.L. Leibel, H. Baumann, and L.A. Tartaglia. 1997. Constitutive and impaired signaling of leptin receptors containing the Gln-Pro extracelluar domain fatty mutation. Proc. Natl. Acad. Sci. USA. 94:10567-10662.

42. Bonner-Weir, S., D.F. Trent, and G.C. Weir. 1983. Partial pancreatectomy in the rat and subsequent defect in glucose-induced insulin release. $J$. Clin. Invest. 71:1544-1553.

43. Poitout, V., and R.P. Robertson. 1996. An integrated view of beta-cell dysfunction in type-II diabetes. Annu. Rev. Med. 47:69-83.

44. Leahy, J.L., and G.C. Weir. 1988. Evolution of abnormal insulin secretory responses during 48-h in vivo hyperglycemia. Diabetes. 37:217-222.

45. Ling, Z., R. Kiekens, T. Mahler, F.C. Schuit, M. Pipeleers-Marichal, A. Sener, G. Kloppel, W.J. Malaisse, and D.G. Pipeleers. 1996. Effects of chronically elevated glucose levels on the functional properties of rat pancreatic betacells. Diabetes. 45:1774-1782.

46. Ling, Z., and D.G. Pipeleers. 1996. Prolonged exposure of human beta cells to elevated glucose levels results in sustained cellular activation leading to a loss of glucose regulation. J. Clin. Invest. 98:2805-2812.

47. Permutt, A., J. Chirgwin, S. Giddings, K. Kakita, and P. Rotwein. 1981. Insulin biosynthesis and diabetes mellitus. Clin. Biochem. 14:230-236.

48. Leahy, J.L., S. Bonner-Weir, and G.C. Weir. 1988. Minimal chronic hyperglycemia is a critical determinant of impaired insulin secretion after an incomplete pancreatectomy. J. Clin. Invest. 81:1407-1414.

49. Unger, R.H. 1995. Lipotoxicity in the pathogenesis of obesity-dependent NIDDM. Genetic and clinical implications. Diabetes. 44:863-870.

50. Koyama, K., G. Chen, Y. Lee, and R.H. Unger. 1997. Tissue triglycerides, insulin resistance, and insulin production: implications for hyperinsulinemia of obesity. Am. J. Physiol. 273:E708-E713.

51. Zhou, Y.P., and V.E. Grill. 1994. Long-term exposure of rat pancreatic islets to fatty acids inhibits glucose-induced insulin secretion and biosynthesis through a glucose fatty acid cycle. J. Clin. Invest. 93:870-876.

52. Grupping, A.Y., M. Cnop, C.G. Van Schravendijk, J.C. Hannaert, T.J. Van Berkel, and D.G. Pipeleers. 1997. Low density lipoprotein binding and uptake by human and rat islet beta cells. Endocrinology. 138:4064-4068.

53. Milburn, J.L., Jr., H. Hirose, Y.H. Lee, Y. Nagasawa, A. Ogawa, M. Ohneda, H. BeltrandelRio, C.B. Newgard, J.H. Johnson, and R.H. Unger 1995. Pancreatic beta-cells in obesity. Evidence for induction of functional, morphologic, and metabolic abnormalities by increased long chain fatty acids. J. Biol. Chem. 270:1295-1299.

54. Shimabukuro, M., K. Koyama, G. Chen, M.Y. Wang, F. Trieu, Y. Lee, C.B. Newgard, and R.H. Unger. 1997. Direct antidiabetic effect of leptin through triglyceride depletion of tissues. Proc. Natl. Acad. Sci. USA. 94:46374641.

55. Lee, Y., H. Hirose, Y.T. Zhou, V. Esser, J.D. McGarry, and R.H. Unger. 1997. Increased lipogenic capacity of the islets of obese rats: a role in the pathogenesis of NIDDM. Diabetes. 46:408-413.

56. Wang, M.Y., K. Koyama, M. Shimabukuro, C.B. Newgard, and R.H Unger. 1998. Ob-Rb gene transfer to leptin-resistant islets reverses diabetogenic phenotype. Proc. Natl. Acad. Sci. USA. 95:714-718.

57. Zhou, Y.T., M. Shimabukuro, Y. Lee, K. Koyama, F. Trieu, and R.H. Unger. 1997. Leptin normalizes the impaired response of proinsulin mRNA to long chain fatty acids in heterozygous Zucker diabetic fatty rats. J. Biol. Chem. 272:25648-25651.

58. Chen, G., K. Koyama, X. Yuan, Y. Lee, Y.T. Zhou, R. O’Doherty, C.B. Newgard, and R.H. Unger. 1996. Disappearance of body fat in normal rats induced by adenovirus-mediated leptin gene therapy. Proc. Natl. Acad. Sci. USA. 93:14795-14799.

59. Koyama, K., G. Chen, M.Y. Wang, Y. Lee, M. Shimabukuro, C.B. Newgard, and R.H. Unger. 1997. Beta-cell function in normal rats made chronically hyperleptinemic by adenovirus-leptin gene therapy. Diabetes. 48:1276-1280.

60. Shimabukuro, M., M. Ohneda, Y. Lee, and R.H. Unger. 1997. Role of nitric oxide in obesity-induced beta cell disease. J. Clin. Invest. 100:290-295.

61. Shimabukuro, M., K. Koyama, Y. Lee, and R.H. Unger. 1997. Leptin- or troglitazone-induced lipopenia protects islets from interleukin 1beta cytotoxicity. J. Clin. Invest. 100:1750-1754.

62. Kajimoto, Y., H. Watada, T. Matsuko, H. Kaneto, Y. Fujitani, J. Miyazaki, and Y. Yamasaki. 1997. Suppression of transcription factor PDX-1/ IPF1/STF-1/IDX-1 causes no decrease in insulin mRNA in MIN6 cells. J. Clin. Invest. 100:1840-1846.

63. Watada, H., Y. Kajimoto, Y. Umayahara, T. Matsuoka, H. Kaneto, Y. Fujitani, T. Kamada, R. Kawamori, and Y. Yamasaki. 1996. The human glucokinase gene $\beta$-cell-type promoter: an essential role of insulin promoter factor 1/PDX-1 in its activation in HIT-T15 cells. Diabetes. 45:1478-1488.

64. Waeber, G., N. Thompson, P. Nicod, and C. Bonny. 1996. Transcriptional activation of the GLUT2 gene by the IPF-1/STF-1/IDX-1 homeobox fac- 
tor. Mol. Endocrinol. 10:1327-1334.

65. Watada, H., Y. Kajimoto, H. Kaneto, T. Matsuoka, Y. Fujitani, J.

Miyazaki, and Y. Yamasaki. 1996. Involvement of the homeodomain-containing transcription factor PDX-1 in islet amyloid polypeptide gene transcription. Biochem. Biophys. Res. Commun. 229:746-751.

66. Jonsson, J., L. Carlsson, T. Edlund, and H. Edlund. 1994. Insulin-promoter-factor 1 is required for pancreas development in mice. Nature. 371:606-609.
67. Stoffers, D.A., N.T. Zinkin, V. Stanojevic, W.L. Clarke, and J.F. Habener. 1997. Pancreatic agenesis attributable to a single nucleotide deletion in the human IPF1 gene coding sequence. Nat. Genet. 15:106-110.

68. Stoffers, D.A., J. Ferrer, W.L. Clarke, and J.F. Habener. 1997. Earlyonset type-II diabetes mellitus (MODY4) linked to IPF1. Nat. Genet. 17:138- 